\title{
FAREWELL TO THE EU CHARTER: BREXIT AND FUNDAMENTAL RIGHTS PROTECTION
}

\author{
MARCO GALIMBERTI*
}

\begin{abstract}
Twenty years after its drafting and more than one decade after its entry into force, the Charter of Fundamental Rights of the European Union has ceased to be part of British law as a consequence of Brexit. Looking into this issue raised by the UK withdrawal from the European Union, the essay sheds some light on the legal status and impact of the EU Bill of Rights in the British legal order. Against this background, the article detects a connection between the UK Supreme Court's case law and the jurisprudence of the Court of Justice of the European Union on the direct effect of the Charter. From this perspective, the analysis highlights the implications of the UK departure from the Charter and disentanglement from the Luxembourg case law, thus arguing that they may weaken the standards of fundamental rights protection.
\end{abstract}

\section{INTRODUCTION}

Borrowing the words of British Prime Minister Boris Johnson, the EU-UK Trade and Cooperation Agreement concluded at the end of last year and approved by the European Parliament in April 2021 marks a 'final step in a long journey' which began nearly five years ago. ${ }^{1}$ With the addition of this latest piece of the puzzle, it can be argued that the UK Government and the European Union eventually managed to lead the Brexit negotiations to a safe harbour, notwithstanding the severe storms that the parties had to navigate through since the very beginning of their journey. Among the variety of legal and constitutional issues that the Brexit process raises and requires to unravel - and on which a great deal of ink has already been spilled so far -, it is hard to deny that one the most intricate matters is the one concerning the future of fundamental rights protection in the UK.

Taking a step backwards, the relevance of this open question has its roots in the European Union (Withdrawal) Act 2018 that the Parliament introduced in order to repeal the European Communities Act 1972 and facilitate legal transition when the UK parts ways with the EU. ${ }^{2}$ Indeed, the Withdrawal Act is predicated on the general assumption that existing EU legislation is converted into UK law as it stands at the moment of Brexit, with the possibility for the UK Parliament and courts to decide thereafter whether to retain,

\footnotetext{
* Post-doc researcher in constitutional law, University of Milano Bicocca, Italy.

The author wishes to thank Xavier Groussot, Stefania Ninatti and the anonymous reviewer for their comments. The usual disclaimer applies.

${ }^{1}$ The so-called 'Trade and Cooperation Agreement between the European Union and the European Atomic Energy Community, of the one part, and the United Kingdom of Great Britain and Northern Ireland, of the other part' was signed on 30 December 2020. It was applied provisionally as of 1 January 2021 and entered into force on 1 May 2021 - Trade and Cooperation Agreement Between the European Union and the European Atomic Energy Community, of the one part, and the United Kingdom of Great Britain and Northern Ireland, of the other part [2020] OJ L 444/14.

2 Subsequently, amendments to the European Union (Withdrawal) Act 2018 were made by the European Union (Withdrawal Agreement) Act 2020 and related provisions concerning the UK-EU Withdrawal Agreement.
} 
amend or repeal it. To be more precise, such logic is reflected in Clauses 2 to 4 of the Bill, which provide that different sources of EU law - such as EU-derived national legislation, direct EU legislation and rights forming part of UK law by virtue of the European Communities Act 1972 - will continue to exist within the British legal order. ${ }^{3}$

Nevertheless, this rationale of legal continuity underlying the Withdrawal Act finds a major exception in Clause 5(4), which expressly excludes the EU Charter of Fundamental Rights (hereinafter, 'the Charter') from being incorporated into domestic law on or after exit day. ${ }^{4}$ At the same time, there is a certain degree of ambiguity surrounding the reading of Clause 5(5) of the Bill, as it affirms in a somewhat cryptic way that such preclusion of the Charter transplant into national legislation 'does not affect the retention in domestic law [...] of any fundamental rights or principles which exist irrespective of the Charter' itself. ${ }^{5}$

Neither it is clear whether those principles being referred to therein do actually correspond with the principles laid down by the Court of Justice of the European Union (hereinafter, 'CJEU'), which will no longer be binding on UK courts and tribunals according to Clause 6(1) of the Withdrawal Act. ${ }^{6}$ In a similar vein, a further interpretative knot to untie lies in the fact that the Bill provides for incorporation of general principles of EU law (including EU fundamental rights) recognised by the CJEU into UK law, ${ }^{7}$ whilst disallowing, however, any right of action relying on them as such. ${ }^{8}$

On top of that, it can also be noticed that the Withdrawal Act sets the survival of the principle of EU law primacy - and the ensuing disapplication of any inconsistent UK law -

\footnotetext{
${ }^{3}$ More specifically, Clause 2 of the Withdrawal Act retains domestic statutes and statutory instruments that implement EU law; Clause 3 refers to direct EU legislation, ie directly applicable EU regulations and decisions, which have legal effect within the national legal framework without the need for any implementing domestic statute; and Clause 4 covers directly effective rights that have hitherto been part of British law under section 2(1) of the European Communities Act 1972. In particular, this latter section states that 'all such rights, powers, liabilities, obligations and restrictions from time to time created or arising by or under the Treaties, and all such remedies and procedures from time to time provided for by or under the Treaties, as in accordance with the Treaties are without further enactment to be given legal effect or used in the United Kingdom shall be recognised and available in law, and be enforced, allowed and followed accordingly'.

${ }^{4}$ For a critical analysis of the decision to exclude the Charter from the general logic underpinning the European Union (Withdrawal) Act, see Nicholas Bamforth, Meghan Campbell, Paul Craig, Sandra Fredman, Stephen Weatherhill and Alison Young, 'The EU Charter After Brexit' (2017) Oxford Human Rights Hub, Submission to Joint Committee on Human Rights < https://ohrh.law.ox.ac.uk/the-eu-charter-after-brexit2017-submission-to-joint-committee-on-human-rights/> accessed 25 May 2021; Arabella Lang, Vaughne Miller, Simson Caird, 'EU (Withdrawal) Bill: the Charter, general principles of EU law, and "Francovich" damages' (2017) House of Commons Library, Research Briefing Paper Number 8140

$<$ https://commonslibrary.parliament.uk/research-briefings/cbp-8140/> accessed 25 May 2021.

5 Accordingly, Clause 5(5) of the Withdrawal Act underlines that 'references to the Charter in any case law are, so far as necessary for this purpose, to be read as if they were references to any corresponding retained fundamental rights or principles'.

${ }^{6}$ As regards this specific point, Clause 6(1) of the Bill provides that a court or tribunal ' (a) is not bound by any principles laid down, or any decisions made, on or after exit day by the European Court, and (b) cannot refer any matter to the European Court on or after exit day'.

${ }^{7}$ See especially Clause 6(3) of the Withdrawal Act, according to which 'any question as to the validity, meaning or effect of any retained EU law is to be decided [...] in accordance with any retained case law and any retained general principles of EU law [...]'.

${ }^{8}$ In this respect, reference should be made to Schedule 1 of the Withdrawal Act, which lays down further provision about exceptions to savings and incorporation. Particularly, Schedule 1 paragraph 2 explains that for a general principle of EU law to be part of domestic law, it has to have been recognised by the CJEU in a case decided before exit day. At the same time, Schedule 1 paragraph 3 makes clear that 'there is no right of action in domestic law on or after exit day based on a failure to comply with any of the general principles of EU law'.
} 
on a slippery slope: on the one hand, Clause 5(1) removes it in relation to statutes adopted post-exit day; ${ }^{9}$ on the other hand, Clause $5(2)$ preserves it as regards legislation enacted prior to exit day; ${ }^{10}$ and, to make matters even more difficult, Clause 5(3) maintains it for laws existing before Brexit and modified afterwards, as long as the purpose of such amendment is consistent with the primaute. ${ }^{11}$

Against this backdrop, one might well wonder what kind of legal implications can be ultimately inferred in terms of fundamental rights protection from the above interlocking elements of complexity set out in the Withdrawal Act. And, in particular, the question arises as to which detrimental effects may stem, in this respect, from the Government's choice to rid itself of the Charter. In order to address this contentious issue, the next pages give firstly a brief overview of the status that the Charter has enjoyed in the UK legal system since its incorporation into the Treaty up to exit day (section 2). Taking the cue from this theoretical framework, the following section of the paper delves into the UK Supreme Court's Benkharbouche decision as a case study which provides a tangible example of the effectiveness of the Charter in domestic jurisprudence (section 3). Broadening the scope of our analysis to the Luxembourg Court, the Benkharbouche judgment offers then the opportunity to envisage the initial seeds of a substantial - and to some extent unpredicted - convergence between the UK case law and the CJEU's jurisprudence on the direct effect of the Charter (section 4). Lastly, the essay will seek to draw some - though still inevitably tentative - conclusions on the basis of the analysis carried out throughout the previous sections (section 5).

\section{THE EU CHARTER OF FUNDAMENTAL RIGHTS IN THE UK}

With a view to framing correctly the present topic and be able to enter into the merits thereof, it is useful to provide, first of all, some basic coordinates relating to the status and incidence of the 'EU Bill of Rights"12 in the British legal system. As is well-known, the Charter was solemnly proclaimed by the EU Parliament, the Council of Ministers and the EU Commission at Nice in December 2000 and acquired binding legal status with the Lisbon

\footnotetext{
${ }^{9}$ According to Clause 5(1) of the Bill, 'The principle of the supremacy of EU law does not apply to any enactment or rule of law passed or made on or after exit day'.

${ }^{10}$ In this regard, Clause 5(2) of the Withdrawal Act states that ' $[. .$.$] the principle of the supremacy of EU law$ continues to apply on or after exit day so far as relevant to the interpretation, disapplication or quashing of any enactment or rule of law passed or made before exit day'.

11 In particular, Clause 5(3) affirms that 'Subsection (1) does not prevent the principle of the supremacy of EU law from applying to a modification made on or after exit day of any enactment or rule of law passed or made before exit day if the application of the principle is consistent with the intention of the modification'. ${ }^{12}$ This expression is inspired by Eddy De Smijter and Koen Lenaerts, 'A "Bill of Rights" for the European Union' (2001) 38 CML Rev 273.
} 
Treaty entry into force on 1 December $2009 .{ }^{13}$ From then on, the Charter forms part of EU primary law and has 'the same legal value as the Treaties' pursuant to Article 6(1) TEU. ${ }^{14}$

Even before the Treaty of Lisbon entered into force, the British Government chaired by the then Prime Minister Tony Blair had bluntly made clear its reluctance to acknowledge the legally binding nature of the Charter in the UK and described it as a mere statement of policy. ${ }^{15}$ Such misgivings about the application of Charter rights seem however to be quite unsurprising in view, more generally, of the traditional dualism characterising the British constitutional approach to international and EU law. ${ }^{16}$ This unfriendly attitude toward the legal enforceability of the EU human rights catalogue took the form of a written document, namely Protocol No 30 on the application of the Charter to the UK (and Poland), which was annexed to the EU Treaties. ${ }^{17}$ The equivocal wording of Protocol No 30 gave rise to a common misunderstanding that the Protocol itself amounts to a sort of opt-out regime from the Charter, ${ }^{18}$ inasmuch as Article 1(1) thereof states that 'the Charter does not extend the

\footnotetext{
${ }_{13}$ With regard to the main goal for EU fundamental rights' codification into a written text, the Presidency Conclusions at the occasion of the European Council of Cologne in 1999 clarified that '[...] at the present stage of development of the European Union, the fundamental rights applicable at Union level should be consolidated in a Charter and thereby made more evident'. Accordingly, the European Council decision on the drawing up of a Charter of Fundamental Rights of the European Union (annex IV) declared that '[...] there appears to be a need, at the present stage of the Union's development, to establish a Charter of fundamental rights in order to make their overriding importance and relevance more visible to the Union's citizens'.

${ }^{14}$ As regards the debate on the legal effects of the Charter and its impact on the EU system of fundamental rights protection, which falls beyond the scope and purposes of the present analysis, see ex multis Joseph Weiler, 'Does the European Union Truly Need a Charter of Rights?' (2000) 6 European Law Journal 95; Bruno De Witte, 'The legal status of the Charter: Vital question or non-issue?' (2001) 8 Maastricht Journal of European and Comparative Law 81; Gráinne De Burca, "The drafting of the European Union Charter of fundamental rights' (2001) 26 European Law Review 126; Piet Eeckhout, 'The EU Charter of Fundamental Rights and the Federal Question' (2002) 39 Common Market Law Review 945, 951; Xavier Groussot and Laurent Pech, 'Fundamental Rights Protection in the European Union Post Lisbon Treaty' Foundation Robert Schuman Policy Paper 173/2010 < https://www.robert-schuman.eu/en/doc/questions-d-europe/qe173-en.pdf $>$ accessed 25 May 2021; Koen Lenaerts, 'Exploring the Limits of the EU Charter of Fundamental Rights' (2012) 8 European Constitutional Law Review 375.

15 To name but a few examples, in October 2000 the then UK Minister for Europe Keith Vaz claimed that 'this is not a litigator's Charter. Nobody can sue on it. Nobody will be able to litigate on it'; similarly, on 22 November 2000 he declared to the House of Commons that the Charter 'will not be legally enforceable'; on 14 November 2000, the Prime Minister Tony Blair stated that the Charter is 'simply a statement of policy and the UK is not the only member state to oppose something of a binding legal nature'; and, in a speech to the House of Common on 11 December 2000, he maintained that 'our case is that [the Charter] should not have legal status and we do not intend it to. We will have to fight that case'.

16 On the UK's dualist approach see, among many others, Margot Horspool, Matthew Humphreys, Michael Wells-Greco, European Union Law (OUP 2018) 199 and Shaheed Fatima, 'The Domestic Application of International Law in British Courts' in Curtis A Bradley (ed), The Oxford Handbook of Comparative Foreign Relations Law (OUP 2019).

17 Protocol (No 30) on the application of the Charter of Fundamental Rights of the European Union to Poland and to the United Kingdom [2008] OJ C 115/313. For a thorough analysis of the Protocol and its contested legal implications see, among others, Anthony Arnull, 'Protocol (No 30) on the Application of the Charter of Fundamental Rights of the European Union to Poland and the United Kingdom' in Steve Peers, Tamara Hervey, Jeff Kenner, Angela Ward (eds), The EU Charter of Fundamental Rights. A Commentary (Hart 2014); Catherine Barnard, 'The 'Opt-Out' for the UK and Poland from the Charter of Fundamental Rights: Triumph of Rhetoric over Reality?’ in Stefan Griller, Jacques Ziller (eds), The Lisbon Treaty: EU Constitutionalism Without a Constitutional Treaty? (Springer 2008).

${ }^{18}$ By way of example, in a statement to the House of Commons on 25 June 2007 Tony Blair affirmed that it is absolutely clear that we have an opt-out from [...] the Charter [...]'. The misconception that the UK had an 'opt-out' from the Charter is also highlighted in Menelaos Markakis, 'Brexit and the EU Charter of Fundamental Rights' (2019) Public Law 82.
} 
ability of the Court of Justice of the European Union, or any court or tribunal [...] of the United Kingdom, to find that the laws, regulations or administrative provisions, practices or action $[. .$.$] of the United Kingdom are inconsistent with the fundamental rights, freedoms$ and principles that it reaffirms'.

Yet, in 2011 the CJEU's ruling in the N.S. case took the chance to explain that Protocol No 30 does not intend to grant any genuine opt-out from the application of the Charter ${ }^{19}$ but it merely accords to the UK (and Poland) a kind of 'comfort clause'. ${ }^{20}$ One year later, it was a decision of the UK Supreme Court to confirm that the Charter - binding the Member States only when they are implementing EU law under Article 51(1) of the Charter - takes effect in the national legal order ${ }^{21}$ and, therefore, to tame the debate that the UK High Court had meanwhile contributed to revive as to the alleged opt-out nature of Protocol No $30 .{ }^{22}$ At a closer look, further evidence of the Charter's binding effects may also be implicitly derived from the two other provisions forming part of the Protocol, which deal with the way that certain rules of the Charter have to be applied in the UK: first, Article 1(2), declaring in rather vague terms that nothing in Title IV of the Charter ('Solidarity') creates justiciable rights applicable to the UK except in so far as such rights are provided for in national law; and, second, Article 2, stressing that where a Charter provision refers to national laws and practices, it shall only apply to the UK to the extent that the rights or principles that it contains are recognised in domestic law or practices. ${ }^{23}$

That being said, although both the CJEU and the UK Supreme Court had already held that Protocol No 30 did not secure any opt-out from the Charter, there appear to persist some concerns as to the exact status of the EU Bill of Rights in the UK. In this context, a 2014 report published by the European Scrutiny Committee of the House of Commons identified confusion about a number of aspects of the Charter's application in UK law and

\footnotetext{
${ }^{19}$ Joined Cases C-411/10 and C-493/10 N. S. v Secretary of State for the Home Department and M. E. and Others v Refugee Applications Commissioner and Minister for Justice, Equality and Law Reform EU:C:2011:865, paras 119-120: '[...] Protocol (No 30) does not call into question the applicability of the Charter in the United Kingdom or in Poland [...]. In those circumstances, Article 1(1) of Protocol (No 30) explains Article 51 of the Charter with regard to the scope thereof and does not intend to exempt the Republic of Poland or the United Kingdom from the obligation to comply with the provisions of the Charter or to prevent a court of one of those Member States from ensuring compliance with those provisions'. In this regard, the Grand Chamber expressly upheld the N.S., Opinion of AG Trstenjak, paras 169-170.

20 This expression is borrowed from Bryn Harris, 'The Charter of Fundamental Rights in UK law after Brexit: Why the Charter should not be transposed' (Lawyers for Britain, 20 November 2017)

$<$ https: / lawyersforbritain.org/why-the-eus-charter-of-fundamental-rights-must-not-be-transposed-into-uklaw $>$ accessed 25 May 2021.

21 The Rugby Football Union v Consolidated Information Services Limited (Formerly Viagogo Limited) [2012] UKSC 55, paras 26-28: 'Although the Charter [...] has direct effect in national law, it only binds member states when they are implementing EU law - article 51(1). But the rubric, 'implementing EU law' is to be interpreted broadly and, in effect, means whenever a member state is acting 'within the material scope of EU law' [...]'. 22 See, in particular, $\mathrm{R}$ (on the application of $A B$ ) v Secretary of State for the Home Department [2013] EWHC 3453, when Mr Justice Mostyn stated as follows: 'I was sure that the British government [...] had secured at the negotiations of the Lisbon Treaty an opt-out from the incorporation of the Charter into EU law and thereby via operation of the European Communities Act 1972 directly into our domestic law. [...] it is absolutely clear that the contracting parties agreed that the Charter did not create one single further justiciable right in our domestic courts'. Nevertheless, he specified that, as a consequence of the recalled CJEU's N.S. judgment, 'Notwithstanding the endeavours of our political representatives at Lisbon it would seem that the much wider Charter of Rights is now part of our domestic law'.

${ }^{23}$ In the abovementioned N.S. judgment (n 19), the CJEU did not rule on the meaning of such provisions, since they were not necessary for deciding the case. By contrast, they were mentioned in the Opinion of AG Trstenjak (n 19), paras 171-176.
} 
invoked, thus, 'an urgent need for clarification, and for action'. ${ }^{24}$ Notably, the report did stress that several legal effects of the Charter were still unclear, including its field of application, the distinction between rights and principles, the relationship with the European Convention on Human Rights (hereinafter, 'ECHR'), and the capacity of the Charter to have horizontal effect between private parties. ${ }^{25}$ On the basis of such remarks, the 2014 study by the European Scrutiny Committee recommended, by way of conclusion, that the Government should intervene in proceedings before the CJEU to limit the scope of the Charter $^{26}$ and also that an Act of Parliament should be passed in order to disapply the Charter in the $\mathrm{UK}^{27}$.

Shortly thereafter, a response of the Government to such report underlined the domestic courts' power to strike down a national statute inconsistent with a directly enforceable right in the Charter; it reiterated that the Charter, as it also states in its preamble, is not intended to establish any new rights but to simply reaffirm rights (and principles) already recognised in EU law; and it clarified that the CJEU had hitherto respected the limits on the application of the Charter. ${ }^{28}$ Among other things, the Government essentially agreed with the Committee's conclusion as to two important differences - which we will come back to in the next section - between the Charter and the ECHR, this latter being given effect in British law through the enactment of the Human Rights Act 1998 ('HRA'). At the outset, it observed that some rights codified in the Charter have a wider scope than the corresponding

\footnotetext{
${ }^{24}$ European Scrutiny Committee - Forty-Third Report, 'The application of the EU Charter of Fundamental Rights in the UK: a state of confusion' (2013-2014) HC979, para 13. Such concerns arose even though the European Scrutiny Committee, in its Third Report of Session, 'EU Intergovernmental Conference: Follow-up Report' (2007-2008), para 38, had argued that 'It is clear that the Government accepts that the Charter will be legally binding, and it has stated that the Protocol is not an opt-out. Since the Protocol is to operate subject to the UK's obligations under the Treaties, it still seems doubtful to us that the Protocol has the effect that the courts of this country will not be bound by interpretations of measures of Union law given by the ECJ and based on the Charter'.

${ }^{25}$ For a critical analysis of the main issues highlighted in the report see Sionaidh Douglas-Scott, 'Fundamental Rights Not Euroscepticism: Why the UK Should Embrace the EU Charter' (2014) Oxford Legal Studies Research Paper 82/2014 < https://papers.ssrn.com/sol3/papers.cfm?abstract_id=2528768> accessed 25 May 2021.

${ }^{26}$ European Scrutiny Committee - Forty-Third Report, 'The application of the EU Charter of Fundamental Rights in the UK: a state of confusion' (2013-2014) HC979, para 169: '[...] We urge the Government to think again, and to intervene in future ECJ cases on the Charter in support of a higher threshold - a determinative link-for the test for when Member State action comes within the scope of EU law, as a consequence of which any human rights aspects fall under the Charter, as interpreted by the ECJ rather than national courts'. Interestingly, the report observed that the UK Government had not intervened before the CJEU in Case C617/10 Aklagaren v Hans Akerberg Fransson EU:C:2013:105, namely the leading authority on the interpretation of Article 51(1) of the Charter.

${ }^{27}$ Forty-Third Report, 'The application of the EU Charter of Fundamental Rights in the UK: a state of confusion' (n 26) para 172: '[...] in particular in relation to the field of application, and the certainty that the jurisdiction of the ECJ will range across an even wider field with increasingly unintended consequences, we recommend that primary legislation is introduced by way of amendment to the European Communities Act 1972 to exclude, at the least, the applicability of the Charter in the UK. This is what most people thought was the effect of Protocol 30. They were wrong. It is not an opt-out, but for the sake of clarity and for the avoidance of doubt we urge the Government to amend the European Communities Act 1972 [...]'. ${ }^{28}$ Government response to the House of Commons European Scrutiny Committee - Forty-Third Report, 'The application of the EU Charter of Fundamental Rights in the UK: a state of confusion' (n 26). A similar stance was also taken by the House of Lords European Union Committee 12th Report, 'The UK, the EU and a British Bill of Rights' (2015-2016) HL Paper 139, 3, stating that 'We also heard a range of views on whether the Court of Justice of the European Union could be accused of extending the scope of EU law over national law through its judgments on the EU Charter. The weight of expert evidence was clear, and did not support such a conclusion'.
} 
ones guaranteed under the ECHR, such as in the case of Article 47 of the Charter (right to an effective remedy and fair trial) compared to Article 6 of the Convention. From the point of view of remedial measures, the Government then recalled that UK judges must disapply a piece of national legislation being at variance with a Charter's directly applicable right, in accordance with the principle of EU law primacy. By contrast, a domestic court can only make a declaration of incompatibility whenever an Act of Parliament is inconsistent with a Convention's right (and therefore with the HRA), without affecting the validity of the Act in question until and unless Parliament amends it.

Last but not least, among the Charter-related studies prior to the European Union (Withdrawal) Act, it is also worth mentioning a 'right by right analysis' the UK Government published in December 2017. ${ }^{29}$ Interestingly enough, the report argued that the substantive rights enshrined in the Charter would not be weakened after exit day: they will find protection in a range of other sources, such as retained EU law, general principles of EU law, common law, other international human rights instruments and domestic statutes, which would fill the gap left by the removal of the Charter in the UK's human rights system. However, relying upon the mere assumption that the Charter's rights will be eventually converted into national law, the Government's assessment appears in fact unable to grasp all the nuances of the matter. Neither the study took into account, for instance, the issue of post-exit enforcement of rights that for the time being have no direct equivalent at all either in the ECHR or in any other relevant sources; $;^{30}$ nor it examined the potential implications of the UK courts' loss of competence to disapply laws that contravene an EU directly enforceable right as a natural consequence of the Charter exclusion. ${ }^{31}$

\section{TAKING THE CHARTER SERIOUSLY: THE FLOOR TO THE COURTS}

In the light of the framework depicted so far, it is now possible to focus in more detail on the judicial impact of the Charter and, particularly, on an exemplary case involving the direct applicability of EU rights in the UK.

According to the EU Fundamental Rights Agency (FRA) database, which collects the case law of the CJEU and the European Court of Human Rights (hereinafter 'ECtHR') with direct references to the Charter, as well as a selection of national jurisprudence from the EU Member States, the CJEU has referred to the EU catalogue of rights in as many as 979 cases

\footnotetext{
29 'Charter of Fundamental Rights of the EU: Right by Right Analysis' (5 December 2017)

<https://www.gov.uk/government/uploads/system/uploads/attachment_data/file/664891/05122017_Cha rter_Analysis_FINAL_VERSION.pdf $>$ accessed 25 May 2021.

${ }^{30}$ For example, the report merely observed that Article 8 of the Charter (protection of personal data) has no direct equivalent in the Convention, or that the scope of the right under Article 47 of the Charter 'is not however identical to that of Article 6 ECHR because it is not limited to the determination of civil rights and obligations or a criminal charge'. With specific regard to Articles 21 (non-discrimination) and 28 (collective bargaining and action), it noted that courts will be required to interpret retained EU law consistently with the Charter 'so far as it reflects a general principle of EU law' as well as that domestic legislation 'covers some of the same ground' as relevant the Charter rights.

${ }^{31}$ In this regard, the study simply stated that ' $[\ldots]$ where the court is currently able to disapply legislation because of incompatibility with that right, it will continue to be able to do so where that retained EU law was passed or made before exit day' (para 22).
} 
(including judgments, orders and opinions). ${ }^{32}$ Among these, 24 case law references are identified as concerning directly the UK. ${ }^{33}$ Even though this overall number may be considered as a quite limited one, especially in comparison to the relevant figures for other Member States such as Germany and Italy, ${ }^{34}$ it is also true that, from a "qualitative" viewpoint, some UK cases have left a strong mark in the Luxembourg jurisprudence since the Charter became legally binding.

Suffice it to remind, first of all, the 2011 N.S. judgment we have already come across, in which the CJEU ruled that Article 4 of the Charter must be interpreted as meaning that national authorities may not transfer an asylum seeker to another Member State if there are substantial grounds for believing that he or she would face a real risk of being subjected to inhuman or degrading treatment due to the systemic deficiencies in that country's asylum procedure and reception conditions. ${ }^{35}$ Another prominent example from the UK can be found in the well-known 2013 Kadi decision, where the CJEU was called to strike a balance between security reasons and restrictive measures to the rights to defence and effective judicial protection guaranteed under the Charter. ${ }^{36}$ And again, touching upon the field of new generation rights, in Tele2 Sverige and Watson the Grand Chamber concluded that Articles 7 (respect for family and private life), 8 (personal data protection) and 11 (freedom of expression and information) of the Charter preclude a national legislation which, for the purpose of fighting crime, provides for general and indiscriminate retention of all traffic and location data ${ }^{37}$ More recently, reference should also be made to the $2018 \mathrm{RO}$ ruling, which took a step forward on the ongoing rapprochement between Charter and ECHR, and therefore between their respective systems of rights protection. ${ }^{38}$ In that circumstance, where the UK had issued a European arrest warrant after the notification of its intention to withdraw from the Union, the legal reasoning of the CJEU went as far as to say that Brexit does not affect the obligation to have due regard to Article 3 ECHR - corresponding to Article 4 of the Charter -, since the continuing participation in the Convention is in no way linked to EU membership. ${ }^{39}$

\footnotetext{
${ }^{32}$ However, this number is to be partially brought down because the database includes also a series of judgments that, despite being prior to the Charter and not referring to it, are still relevant for the applicability thereof.

33 Additionally, the database includes eighteen cases referring to Ireland. Among these, it is worth mentioning the judgment in Case C-327/18 Minister for Justice and Equality v RO EU:C:2018:733 Minister for Justice and Equality $v$ RO and the relating AG Szpunar's opinion, which deal with the Brexit dynamics.

34 According to the FRA database, there have been sixty cases involving Germany and forty-one cases from Italy with direct references to the Charter. Thirty-eight case law references can also be found with regard to Spain, whilst only sixteen cases originated from France.

35 N.S. (n 19).

${ }^{36}$ Joined Cases C-584/10 P, C-593/10 P and C-595/10 P European Commission and Others v Yassin Abdullab Kadi, EU:C:2013:518.

${ }^{37}$ Joined Cases C-203/15 and C-698/15 Tele2 Sverige AB v Post- och telestyrelsen and Secretary of State for the Home Department v Tom Watson and Others EU:C:2016:970.

38 As to the relationship between the Charter and the ECHR, we should also recall Article 52(3) of the Charter, which stipulates that 'In so far as this Charter contains rights which correspond to rights guaranteed by the Convention for the Protection of Human Rights and Fundamental Freedoms, the meaning and scope of those rights shall be the same as those laid down by the said Convention. This provision shall not prevent Union law providing more extensive protection'.

${ }^{39}$ Minister for Justice and Equality $v$ RO (n 33) para 52. According to the CJEU, the decision of a Member State to withdraw from the Union cannot consequently 'justify the refusal to execute a European arrest warrant on the ground that the person surrendered would run the risk of suffering inhuman or degrading treatment within the meaning of those provisions'.
} 
Shifting then the lens of our current analysis from the Luxembourg jurisdiction to the domestic case law, a recent research illustrates that, after the Lisbon Treaty entry into force, UK courts have made 526 references to the Charter. ${ }^{40}$ It goes without saying that this number inevitably takes into consideration a multitude of cases in which the Charter has a limited impact or plays a mostly ornamental role, as it is cited in passing or is just referred to by the legislation mentioned therein. This being so, one of the most relevant findings for present purposes is that the case search suggests an increasing frequency of references to the Charter in post-Lisbon litigation both at Court of Appeal and Supreme Court level. ${ }^{41}$ While the Charter has carved out ever greater visibility as a reference point in the fundamental rights domain, the UK Supreme Court has in some cases continued to place reliance primarily on national law (including the ECHR as incorporated into the HRA) when both domestic and EU fundamental rights apply. ${ }^{42}$ Nonetheless, when it comes to assessing the effectiveness of the remedies available in case of a breach of such rights, we cannot overlook the fairly different kind of protection that the Charter offers as compared to the one provided under domestic sources of law. To give a concrete example of such inconsistency, the enhanced remedial value of the Charter has distinctly come to the fore in Benkharbouche.

The joined cases of Benkharbouche $v$ Embassy of the Republic of Sudan and Janah v Libya originated from the complaints raised by two non-UK nationals formerly working as domestic staff in the Sudanese and Libyan embassies in London. The applicants claimed the alleged infringement of their employment rights and the Working Time Regulations 1998, which had implemented the EU Working Time Directive in the UK. ${ }^{43}$ By contrast, both foreign embassies opposed these claims by invoking State immunity in national courts under sections 4(2)(b) and 16(1)(a) of the State Immunity Act 1978 (hereinafter, 'SIA'). ${ }^{44}$

At the outset, two separate Employment Tribunals dismissed the complaints on the ground that the employers were entitled to State immunity pursuant to the SIA. In 2014, appeals from the first instance decisions were heard together by the Employment Appeal Tribunal ('EAT'), ${ }^{45}$ which held that there had been a violation of right to a fair trial under Article 6 ECHR. ${ }^{46}$ In addition, the EAT found the contested provisions to be in conflict with

\footnotetext{
${ }^{40}$ Lady Arden and Takis Tridimas, 'Limited But Not Inconsequential: The Application of the Charter by the Courts of England and Wales' in Michal Bobek and Jeremias Adams-Prassl (eds), The EU Charter of

Fundamental Rights in the Member States (Hart 2020) 331-332.

41 ibid 332.

${ }^{42}$ See, in an exemplary way, $\mathrm{R}$ (on the application of UNISON) v Lord Chancellor [2017] UKSC 51.

${ }^{43}$ Ms Benkharbouche brought claims against the Sudanese embassy for wrongful dismissal, failure to pay the minimum wage and breach of the Working Time Regulations 1998. Ms Janah brought claims against the Libyan embassy for wrongful dismissal, unpaid wages, racial discrimination, harassment and infringement of the Working Time Regulations 1998.

${ }^{44}$ In particular, section 4(1) SIA removes immunity in proceedings relating to a contract of employment made or due to be performed wholly or partly in the UK. However, section 4(2)(b) SIA reinstates immunity if at the time when the contract was entered into the employee was neither a national of the UK nor habitually resident there. Section 16(1)(a) SIA provides that the exception to immunity under section 4 SIA does not apply to proceedings concerning the employment of members of a mission within the meaning of the Vienna Convention on Diplomatic Relations (1961) or of members of a consular post within the meaning of the Vienna Convention on Consular Relations (1963).

${ }^{45}$ Benkharbouche and Janah v Embassy of the Republic of Sudan and Libya UKEAT/0401/12/GE and UKEAT/0020/13/GE [2014] ICR 169. For an analysis of the case, Andrew Sanger, 'The State Immunity Act and the Right of Access to a Court' (2014) 73 CLJ 1.

${ }^{46}$ However, the EAT is not entitled to make a declaration of incompatibility pursuant to section 4(2) of the Human Rights Act 1998. As a matter of fact, the HRA empowers only higher courts to issue a declaration of incompatibility between an Act of Parliament and the ECHR.
} 
the right to an effective remedy as protected by Article 47 of the Charter. One year later, the UK Court of Appeal reached the same conclusions, thereby paving the way for a double remedial track. ${ }^{47}$ On the one side, it issued a declaration of incompatibility for the challenged sections of the SIA insofar as they infringed the Convention. ${ }^{48} \mathrm{On}$ the other side, in relation to those parts of the claims falling within the scope of EU law, it found the domestic provisions at stake to be contrary to the Charter and hence to be subject to disapplication. In this regard, it recognised the right to an effective remedy as a general principle of EU law and Article 47 as falling into the category of the Charter's provisions endowed with horizontal direct effect (ie direct applicability against private parties). ${ }^{49}$

In 2017, the UK Supreme Court affirmed the order of the Court of Appeal. ${ }^{50}$ After reviewing the relevant international law - and especially the ECtHR's case law -, it upheld that the contested sections of the SIA were at variance with Article 6 ECHR. ${ }^{51}$ No separate issue was needed as to the claims grounded on EU law: if the Convention is infringed, so will be the Charter as well, by reason of the similar (albeit not identical) scope of Article 6 ECHR and Article 47 of the Charter. ${ }^{52}$ It follows, therefore, that national statutes are disapplied due to their inconsistency with a directly enforceable right and that both cases shall be remitted to the Employment Tribunal in order to determine on the merits the EU law-based claims.

Although, at a first glance, the legal reasoning of the UK Supreme Court appears mostly centred around Article 6 ECHR, it is worth dwelling in more depth on its comparison with the judicial remedy available from the perspective of EU law. The decision confirmed that, in a case of conflict between a directly applicable right of the Charter and a piece of domestic legislation, the former necessarily prevails over the latter, which shall be disapplied.

\footnotetext{
47 Benkharbouche and Janah v Embassy of the Republic of Sudan and Libya [2015] EWCA Civ 33. For an analysis of the judgment delivered by the UK Court of Appeal see ex multis Andrew Sanger, 'State Immunity and the Right of Access to a Court under the EU Charter of Fundamental Rights' (2016) 65 ICLQ 213; Katja S. Ziegler, 'Immunity versus Human Rights: The Right to a Remedy after Benkharbouche' (2017) 17 Human Rights Law Review 127; Richard Garnett, 'State and Diplomatic Immunity and Employment Rights: European Law to the Rescue?', (2015) 64 ICLQ 783; Philippa Webb, 'The Immunity of States, Diplomats and International Organizations in Employment Disputes: The New Human Rights Dilemma?' (2016) 27 European Journal of International Law 753; Steven Peers, 'Rights, remedies and state immunity: the Court of Appeal judgment in Benkharbouche and Janah' (European Law Blog, 6 February 2015),

$<$ www.eulawanalysis.blogspot.com/2015/02/rights-remedies-and-state-immunity.html> accessed 25 May 2021.

48 The Court of Appeal found a violation of Article 6 ECHR, in partial conjunction with prohibition of discrimination under Article 14 ECHR. The ruling held that the relevant provisions of the SIA could not be read down and be given effect in a way which is compatible with the ECHR, in accordance to the interpretative obligation imposed by section 3(1) HRA.

49 Benkharbouche and Janah v Embassy of the Republic of Sudan and Libya [2015] EWCA Civ 33, paras 76-81. Notably, in Benkharbouche the UK courts treated the respondents as private parties for the purpose of the employment claims, since non-EU States are not bound by EU law as States.

${ }^{50}$ Benkharbouche v Secretary of State for Foreign and Commonwealth Affairs: Secretary of State for Foreign and Commonwealth Affairs and Libya v Janah [2017] UKSC 62. For a comment on this decision, Andrew Sanger, 'The limits of state and diplomatic immunity in employment disputes' (2018) 77 CLJ 1; Aidan O'Neill, 'The UK Supreme Court and EU law in the Legal Year 2016-2017 - Part 2' (EUtopia law, 27 October 2017) <www.eutopialaw.com/2017/10/27/the-uk-supreme-court-and-eu-law-in-the-legal-year-2016-2017-part-2/> accessed 25 May 2021; Alison Young, 'Benkharbouche and the future of disapplication' (UK Constitutional Law Association, 24 October 2017) <www.ukconstitutionallaw.org/2017/10/24/alison-young-benkharbouche-andthe-future-of-disapplication/> accessed 25 May 2021.

${ }^{51}$ Benkharbouche v Secretary of State for Foreign and Commonwealth Affairs: Secretary of State for Foreign and Commonwealth Affairs and Libya v Janah [2017] UKSC 62, para 76.

52 ibid para 78.
} 
Conversely, when an Act of Parliament is found to breach the ECHR (that is to say, the HRA), such statute shall just be declared incompatible with the Convention: it will then be up to the legislator to intervene, at a later stage, in order to set it aside. ${ }^{53}$

Having said that, it seems that the Supreme Court could easily confine its legal reasoning within the boundaries of the sole infringement of Article 6 ECHR. In so doing, once the challenged provisions are found to be in conflict with the Convention, it would eventually give the ball back to the Parliament, namely the only authority entitled to amend, replace or repeal national legislation. ${ }^{54}$ However, in the present case, the Supreme Court did not hesitate to rely upon the primacy of EU law and the direct effect of the Charter, ${ }^{55}$ so as to empower domestic courts and tribunals to promptly disapply an Act of Parliament.

In view of the example set by Benkharbouche, it is all the more clear that the Charter provides a stronger and more straightforward remedy than the one being available, in the meanwhile, under national law. ${ }^{56}$ Admittedly, a declaration of incompatibility stemming from a breach of the HRA would amount, as such, to no more than a mere 'Pyrrhic victory. ${ }^{57}$ As a matter of fact, the applicants would still have to bring their claims before the ECtHR in order to obtain compensation after all internal remedies are exhausted. Moreover, as we have noticed, a subsequent decision by the Parliament would anyway be needed for the purposes of adjusting or striking down the contested provisions.

With this in mind, in the decision of the Withdrawal Bill to sever ties with the Charter we can ultimately grasp the signs of the well-known objective of 'bringing rights back home' which has long nourished, more in general, a disenchantment with and an internal front of resistance to the multilevel system of fundamental rights protection. ${ }^{58}$ Still, as we have seen, this choice may be considered as a highly risky move, given that it will henceforth deprive the UK legal order of a legal tool through which each and every judge is in the position to safeguard rights more rapidly and secure more immediate relief to the individual than the national sources of law.

\footnotetext{
${ }^{53}$ Benkharbouche v Secretary of State for Foreign and Commonwealth Affairs: Secretary of State for Foreign and Commonwealth Affairs and Libya v Janah [2017] UKSC 62, para 78: 'a conflict between EU law and English domestic law must be resolved in favour of the former, and the latter must be disapplied; whereas the remedy in the case of inconsistency with article 6 of the ECHR is a declaration of incompatibility'.

${ }_{54}$ As regards the declaration of incompatibility, Benkharbouche and Janah $v$ Embassy of the Republic of Sudan and Libya [2015] EWCA Civ 33, para 72 made clear that such remedy 'does not affect the operation or validity of the SIA. The declaration acts primarily as a signal to Parliament that it needs to consider amending that legislation'.

${ }^{55}$ In this respect, Young (n 50) underlined that the Supreme Court's judgment R (Miller) $v$ The Secretary of State for Exiting the European Union [2017] UKSC 5, confirming the primacy of EU law over domestic legislation, affected not only the timing but also the importance of the Benkharbouche decision.

56 On this remedial added value of the Charter see, among others, Arden and Tridimas (n 40); Sanger 'State Immunity' (n 47) 218; Mark Elliott, Stephen Tierney and Alison Young, 'Human Rights Post-Brexit: The Need for Legislation?' (Public Law for Everyone, 8 February 2018)

<www.publiclawforeveryone.com/2018/02/08/human-rights-post-brexit-the-need-for-legislation/> accessed 25 May 2021.

${ }^{57}$ Concurring with this view, among others, Ziegler (n 47) 150 and Garnett (n 47) 812.

${ }^{58}$ See, ex multis, Stephanie Palmer, '7 The Human Rights Act 1998: Bringing Rights Home' (1998) 1 Cambridge Yearbook of European Legal Studies 125; Sarah Lambrecht, 'Bringing Rights More Home: Can a Home-grown UK Bill of Rights Lessen the Influence of the European Court of Human Rights?’ (2014) 15 German Law Journal 407; Graham Gee, 'Leaving Strasbourg? Reforming the Human Rights Act', (2015) 3 Quaderni costituzionali 808. More recently, Conor Gearty, 'States of denial. What the search for a UK Bill of Rights tells us about human rights protection today’ (2018) 5 European Human Rights Law Review 415.
} 


\section{THE DIRECT EFFECT OF THE CHARTER: AN UNEXPECTED EU-FRIENDLINESS?}

The above statement made in Benkharbouche that Article 47 of the Charter has horizontal direct effect in UK law unveils an element of interest not only in terms of hierarchy of norms and relating remedial measures, but also from the point of view of judicial relationships within the multilevel fundamental rights realm. As a matter of fact, it can be highlighted that this stance taken by the UK Court of Appeal - as it also did, in the same year, in its VidalHall ruling ${ }^{59}$ - and later confirmed by the UK Supreme Court aligns in full with the everevolving case law of the CJEU on the matter.

In this respect, shortly after Benkharbouche and in parallel with the British divorce from the Union, the issue of horizontal direct effect of the Charter came to the fore in the CJEU's Egenberger decision. ${ }^{60}$ This 2018 judgment represents indeed one of the most recent (and groundbreaking) bricks the Luxembourg Court has added to a well-rooted string of cases starting from the seminal $V$ an Gend and $\operatorname{Loss}^{61}$ and passing, just to name a few, through Defrenne ${ }^{62}$, Mangold, $^{63}$ Kücükdeveci $^{64}$ and Association de médiation sociale ${ }^{65}$ - dealing with the direct effect of EU law. ${ }^{66}$ In a nutshell, the step up that Egenberger witnessed from the previous CJEU's case law consists of the acknowledgment of horizontal direct effects for Article 21 (prohibition of discrimination) and Article 47 of the Charter. ${ }^{67}$ More precisely, the CJEU made clear that both provisions are sufficient in themselves and do not need to be specified

59 Vidal-Hall v Google Inc [2015] EWCA Civ 311. In this judgment, concerning the matter of data protection, the UK Court of Appeal found that Articles 7, 8 and 47 of the Charter enjoy horizontal direct effect. See also Secretary of State for the Home Department v Davis MP \& Ors [2015] EWCA Civ 1185, when the Court of Appeal referred questions to the Luxembourg Court on the interpretation of the CJEU's Digital Rights Ireland regarding the retention of communications data.

${ }^{60}$ Case C-414/16 Vera Egenberger v Evangelisches Werk für Diakonie und Entwicklung e.V EU:C:2018:257.

${ }^{61}$ Case 26/62 V an Gend and Loos EU:C:1963:1.

${ }^{62}$ Case C-43/75 Gabrielle Defrenne v Société anonyme belge de navigation aérienne Sabena EU:C:1976:56.

${ }^{63}$ Case C-144/04 Werner Mangold v Rüdiger Helm EU:C:2005:709.

${ }^{64}$ Case C-555/07 Seda Kücükdeveci v Swedex GmbH \& Co. KG EU:C:2010:21.

${ }^{65}$ Case C-176/12 Association de médiation sociale v Union locale des syndicats CGT and Others EU:C:2014:2.

${ }^{66}$ On the horizontal direct effect of EU fundamental rights see, among others, Eleni Frantziou, The Horizontal Effect of Fundamental Rights in the European Union: A Constitutional Analysis (OUP 2019); Sonya Walkila, Horizontal Effect of Fundamental Rights in EU Law (Europa Law Publishing 2016); Eleni Frantziou, 'The Horizontal Effect of the Charter of Fundamental Rights of the EU: Rediscovering the Reasons for Horizontality' (2015) 21 European Law Journal 657; Eleanor Spaventa, 'The Horizontal Application of Fundamental Rights as General Principles of Union Law' in Anthony Arnull and others (eds), A Constitutional Order of States - Essays in Honour of Alan Dashwood (Hart 2011) 199; Dorota Leczykiewicz, 'Horizontal Application of the Charter of Fundamental Rights' (2013) 38 European Law Review 479; Xavier Groussot, 'Direct Horizontal Effect in EU Law after Lisbon - The Impact of the EU Charter of Fundamental Rights on Private Parties' in Patrik Lindskoug and others (eds), Essays in Honour of Michael Bogdan (Juristförlaget 2013). On this topic, see also the in-depth analysis provided in this Journal by Graham Butler, Marius Meling, 'Horizontal Direct Effect of the Charter in EU Law: Ramifications for the European Economic Area' (2020) 2 Nordic Journal of European Law 1.

${ }^{67}$ For a comment on this case, Ronan McCrea, 'Salvation outside the church? The CJEU rules on religious discrimination in employment' (European Law Blog, 18 April 2018)

$<$ http://eulawanalysis.blogspot.com/2018/04/salvation-outside-church-ecj-rules-on.html> accessed 25 May 2021; Eleni Frantziou, 'Mangold Recast? The CJEU's Flirtation with Drittwirkung in Egenberger' (European Law Blog, 24 April 2018) <www.europeanlawblog.eu/2018/04/24/mangold-recast-the-CJEUs-flirtation-withdrittwirkung-in-egenberger/> accessed 25 May 2021; Aurelia Colombi Ciacchi, 'Egenberger and Comparative Law: A Victory of the Direct Horizontal Effect of Fundamental Rights' (2018) 5 European Journal of Comparative Law and Governance 207; Ciarán O’Mara, 'Horizontal enforcement of general principles of EU employment equality law - Mangold revisited' (2018) 15 Irish Employment Law Journal 91. 
either by EU or national law in order to confer on individuals 'a right they may rely on as such' in disputes arising in a field covered by EU law. ${ }^{68}$ On this basis, it drew the conclusion that domestic courts have to ensure judicial protection deriving from the Charter and guarantee its full effectiveness 'by disapplying if need be any contrary provision of national law'. ${ }^{69}$

Going beyond the milestone it set in Egenberger, the CJEU has also recognised horizontal direct applicability to other provisions of the Charter, such as Article 31(2) in the Max-Planck-Gesellschaft $t^{70}$ and Bauer and Broßonn ${ }^{71}$ cases. $^{72}$ One year later, this ongoing trend has known a further step forward in Cresco Investigation, ${ }^{73}$ where the CJEU inferred from the horizontal direct effect of the Charter not only an obligation for lower courts to disapply a conflicting national provision but even a duty to apply, instead of it, any domestic statute granting a higher level of protection. ${ }^{74}$

Whereas there is no doubt that such ever-expanding jurisprudence on the direct effect of the Charter has gained momentum over the past few years, the question arises as to whether it will still be possible for UK courts to keep following in the CJEU's footsteps after Brexit and the consequent departure from the EU Bill of Rights. According to the Withdrawal Act, as we have pointed out earlier, an option to fill the void left by the removal of the Charter - and the disentanglement from the CJEU's case law - is that such rights may continue to apply to the UK in the form of unwritten general principles of EU law. ${ }^{75}$

\footnotetext{
${ }^{68}$ Egenberger (n 60) paras 76-78.

${ }^{69} \mathrm{ibid}$ para 79. After Egenberger, in IR $v$ JQ the CJEU held that 'the prohibition of all discrimination on grounds of religion or belief, now enshrined in Article 21 of the Charter, is therefore a mandatory general principle of EU law and is sufficient in itself to confer on individuals a right that they may actually rely on in disputes between them in a field covered by EU law [...] Accordingly, in the main proceedings, if it considers that it is impossible for it to interpret the national provision at issue in a manner that is consistent with EU law, the referring court must disapply that provision'. See Case C-68/17 IR v JQ, EU:C:2018:696, paras 69-70. For a comment on this case, Ronan McCrea, 'Religious discrimination at work: Can employees be fired for getting divorced?' (European Law Blog, 12 September 2018)

$<$ www.eulawanalysis.blogspot.com/2018/09/religious-discrimination-at-work-can.html> accessed 25 May 2021.

${ }^{70}$ Case C-684/16 Max-Planck-Gesellschaft zur Förderung der Wissenschaften eV v Tetsuji Shimizu EU:C:2018:874. 71 Joined Cases C-569/16 and C-570/16 Stadt Wuppertal v Maria Elisabeth Bauer and Volker Willmeroth v Martina Broßonn EU:C:2018:871. For a comment see Eleni Frantziou, '(Most of) The Charter of Fundamental Rights Is Horizontally Applicable: Joined cases C-569/16 and C-570/16 Bauer et al’ (European Law Blog, 19 November 2018), <www.europeanlawblog.eu/2018/11/19/joined-cases-c-569-16-and-c-570-16-bauer-et-almost-of-the-charter-of-fundamental-rights-is-horizontally-applicable/> accessed 25 May 2021; Daniel Sarmiento, 'Sharpening the Teeth of EU Social Fundamental Rights: A Comment on Bauer' (Despite Our Differences Blog, 8 November 2018),

$<$ https://despiteourdifferencesblog.wordpress.com/2018/11/08/sharpening-the-teeth-of-eu-socialfundamental-rights-a-comment-on-bauer/> accessed 25 May 2021.

${ }^{72}$ In Bauer and Broßonn ( $\mathrm{n}$ 71) para 85, the CJEU argued that 'The right to a period of paid annual leave, affirmed for every worker by Article 31(2) of the Charter [...] is sufficient in itself to confer on workers a right that they may actually rely on in disputes between them and their employer in a field covered by EU law and therefore falling within the scope of the Charter'.

${ }^{73}$ Case C-193/17 Cresco Investigation GmbH v Markus Achatri EU:C:2019:43.

$74 \mathrm{ibid}$ para 80. In that case concerning discrimination on grounds of religion under Article 21 of the Charter the CJEU held that 'a national court must set aside any discriminatory provision of national law, without having to request or await its prior removal by the legislature, and must apply to members of the disadvantaged group the same arrangements as those enjoyed by the persons in the other category'. ${ }^{75}$ Interestingly, Takis Tridimas noticed that such general principles 'are unwritten principles of law extrapolated by the [EU] Court from the laws of the Member States by a process similar to that of the development of the common law by the English courts'. See Takis Tridimas, The General Principles of EU Law (Oxford EC Law Library 1999) 4.
} 
However, the viability of this solution envisaged in the Withdrawal Bill has yet to be proven, considering that it will largely depend on the courts' degree of judicial activism, and insofar as general principles with the same content as the rights embedded in the Charter could be said to exist. Apart from the notable exception of the right to an effective remedy and to a fair trial under Article 47 of the Charter, hailed in Benkharbouche as a general (and horizontally enforceable) principle forming an integral part of UK law, it is not easy to foresee now whether and to what extent the same rationale may also encompass other Charter rights and the acknowledgment of their horizontal direct effects. What is more, we should also bear in mind that only those general principles recognised as such by the CJEU before exit day would be retained; ${ }^{76}$ and, on top of that, even the retained general principles could be used only for interpreting retained EU law rather than for challenging and disapplying domestic legislation. ${ }^{77}$

In addition to this (still somewhat blurred) overlap between EU fundamental rights and general principles of EU law, the enhanced centrality of the Charter discourse in the UK jurisprudence finally allows to hint at a further cause for reflection. Broadening the scope of our analysis in a comparative perspective, the position taken by the UK Court of Appeal and Supreme Court can be framed within the context of a growing tendency to use the Charter as a standard of judicial review of laws which has been under way in several foreign jurisdictions. Over the last decade, a series of national Constitutional Courts in Europe have in fact started placing much emphasis on the inherent constitutional nature of the Charter in so-called cases of 'dual preliminarity', that is to say when the same piece of legislation raises questions of constitutionality and, in the meantime, doubts of compatibility with EU law. ${ }^{78}$

Among the rationales underpinning this fine-tuning there is also the perception that, in such circumstances, an extensive reliance by lower courts on the direct effects of the Charter and the preliminary reference mechanism under Article 267 TFEU could jeopardise the precedence that the interlocutory review of constitutionality has usually enjoyed over the preliminary ruling procedure itself in domestic case law. ${ }^{79}$ In order to avert the risk that an ever closer 'partnership' between common judges and the CJEU through the avenue of preliminary ruling, along with the remedy of disapplication, could place constitutional justice at the margins of the multilevel system of fundamental rights protection in the European legal space, the Austrian Verfassungsgerichtshof ${ }^{80}$ as well as, more recently, the Italian Corte costituzionale $^{81}$ and the German Bundesverfassungsgericht $f^{2}$ have begun to claim a 'right to speak

\footnotetext{
${ }^{76}$ European Union (Withdrawal) Act 2018, Clause 6(7) and Schedule 1 para 2.

77 ibid Schedule 1 paras 2 and 3.

${ }^{78}$ On the matter of dual preliminarity in multilevel contexts, Giuseppe Martinico, 'Multiple loyalties and dual preliminarity: The pains of being a judge in a multilevel legal order' (2012) 10 International Journal of Constitutional Law 871.

${ }^{79}$ For a more detailed analysis of this Charter-centred case law, Marco Galimberti, 'From Good Neighbours to Brothers in Arms? The EU Charter as Avenue for Horizontal Constitutional Interaction' (2021) 1 Europarättslig tidskrift 29.

${ }^{80}$ Austrian Constitutional Court, Joined Cases U 466/11-18 and U 1836/11-13, Judgment of 14 March 2012. ${ }^{81}$ Italian Constitutional Court, Judgment no. 269 of 2017, followed by Judgments no. 20 of 2019 and no. 63 of 2019 .

${ }^{82}$ German Federal Constitutional Court, Order of the First Senate of 6 November 2019, 1 BvR 16/13 (Right to be forgotten I) and Order of the First Senate of 6 November 2019, 1 BvR 276/17 (Right to be forgotten II).
} 
first' (ie prior to the CJEU) and, in certain cases, even to make their own preliminary reference to Luxembourg. ${ }^{83}$

A joint reading of the direction undertaken by such Constitutional Courts with longstanding traditions and the UK case law to which we have previously referred leads us to draw a twofold set of considerations. The first finding to be derived therefrom lies in the fact that the use of the Charter as a benchmark of judicial review of laws may be deemed as a common thread running through an array of national constitutional jurisdictions. As we have noted, the direct enforceability of EU fundamental rights has smoothly penetrated and found fertile ground by now also in the UK legal order, where the binding nature of the Charter has long been under discussion, and even in the midst of the Brexit process.

Yet, at the same time, it is possible to distinguish from such element of commonality a countertrend factor: unlike the foreign case law, the alignment between the British judges and the CJEU is at odds with the efforts to curb the spill-over effect of the Charter that is feared to take over, at the expense of Constitutional Courts, in other national legal frameworks. ${ }^{84}$ In this sense, the voice of the UK Supreme Court can be said to rise in antithesis to the one of its brethren within the European choir, of which it has ceased however to be part shortly thereafter with the advent of Brexit. The incorporation of the Charter in constitutional adjudication seems, thus, to branch off into two different tracks which coexist within the EU judicial architecture: for centralized systems of constitutional justice such as the Austrian, Italian and German ones, it has moved towards a strengthening of the Constitutional Courts' status in the fundamental rights domain; whereas for the UK constitutional design it has been liable to reinforce, before exit day, the authority of lower courts as fundamental rights gatekeepers.

\section{CONCLUSION}

Curiously enough, it is precisely in a time of Brexit that the Charter has given concrete evidence to be quite an effective tool for rights protection in the hands of domestic courts and tribunals. Even though it still remains to be seen what path the UK case law will be taking in the fundamental rights realm in the aftermath of the recently completed divorce from the Union - and, in particular, from the Charter -, we may already seek to add some concluding remarks on the basis of the analysis conducted so far. In this regard, the first firm point that can be set is of a "substantial" nature.

In fact, there is no question that the Withdrawal Act's decision not to retain the Charter in the UK legal system expunges from it a contemporary catalogue of rights which, despite its narrower scope of application if compared to the ECHR, contains a far-reaching series of rights that cannot be found either in the text of the Convention or in its Protocols. This is especially true, for instance, when it comes to new rights having no counterpart in the Convention and in the HRA, such as a right to dignity, a right to protection of personal data and a broader right to a fair trial, as well as social and equality rights. In addition to this

\footnotetext{
${ }^{83}$ See, in particular, Orders no. 117 of 2019 and no. 182 of 2020 by the Italian Constitutional Court. ${ }^{84}$ As regards the possibility that the failure to abide by the material limits laid down in Article 51 of the Charter could ultimately result in a spill-over effect thereof, see Augusto Barbera, 'La Carta dei diritti: per un dialogo fra la Corte italiana e la Corte di giustizia' (AIC, 6 November 2017) <https://www.rivistaaic.it/images/rivista/pdf/4_2017_Barbera.pdf> accessed 25 May 2021.
} 
capacity to transcend the contents of the ECHR on account of rights not enumerated in the Convention, it should not be forgotten that, pursuant to Article 52(3) of the Charter, even when the rights of the Charter are similar in content to those of the ECHR, the former may set a higher standard of protection than the latter. ${ }^{85}$ And besides, the farewell to the EU Bill of Rights means, as we have seen, that UK judges are also prevented from relying on the CJEU's ever-evolving interpretation of the Charter and the acknowledgment of its direct effects after exit day.

Along with the substantial standpoint, a second key element to be given due attention pertains then to a more 'procedural' dimension. As the Benkbarbouche case has shown in a paradigmatic way, the removal of the Charter from the UK legal order entails the loss of a stronger remedy available to the litigants (the disapplication of a domestic statute) in comparison to the weaker one being enforceable under the HRA (the declaration of incompatibility). ${ }^{86}$ As to the crucial diversity in terms of efficacy between the two measures at issue, some legal experts have perceptively summarised that

[...] declarations of incompatibility do not quash legislation, or render it unlawful. Legislation declared incompatible with Convention rights continues to apply and have legal effect. However, the declaration sends a political signal to the Government and the legislature that an Act of Parliament is incompatible with Convention rights, providing an opportunity for Parliament to consider whether the legislation should be changed. In EU law, a stronger remedy is available. Both the Charter and general principles of EU law can [...] be used to disapply legislation. This means that the legislative provision which harms human rights does not have legal effect. The rights of the individual before the court can be protected as the legislation harming those rights is not applied to them. ${ }^{87}$

In view of the above, what can thus be argued from both a substantial and procedural perspective is that the choice of the Withdrawal Bill to do without the Charter - and to fill such gap exclusively through national legislation and the aleatory category of general principles of EU law - raises more than one doubt in terms of legal certainty; ${ }^{88}$ and, as such, it is likely to ultimately bring about a certain degree of deficit for the protection of individuals' rights. ${ }^{89}$ Moreover, as we have observed, it goes without saying that the removal of the Charter will end up precluding the ongoing discovery of its 'yet unfulfilled potential', ${ }^{90}$ suffice

85 (n 38).

${ }^{86}$ For a dissenting view, arguing in support of the Withdrawal Bill's choice to exclude the Charter, see Harris (n 20).

87 Elliott, Tierney and Young (n 56).

${ }^{88}$ On the legal uncertainty in which the exclusion of the Charter will result see also, more specifically, Tobias Lock, 'What Future for the Charter of Fundamental Rights in the UK?' (European Futures, 6 October 2017)

<https://www.europeanfutures.ed.ac.uk/what-future-for-the-charter-of-fundamental-rights-in-the-uk/> accessed 25 May 2021 and Bamforth, Campbell, Craig, Fredman, Weatherhill and Young (n 4) 1.

${ }^{89}$ In line with this view, Merris Amos, 'Red Herrings and Reductions: Human Rights and the EU (Withdrawal) Bill' (UK Constitutional Law Association, 4 October 2017)

$<$ https://ukconstitutionallaw.org/2017/10/04/merris-amos-red-herrings-and-reductions-human-rights-andthe-eu-withdrawal-bill/> accessed 25 May 2021; Tobias Lock, 'Human Rights Law in the UK after Brexit' Edinburgh School of Law Research Paper 17/2017 1; Adrienne Yong, 'Forgetting Human Rights - The Brexit Debate' (2017) 5 European Human Rights Law Review 469; Markakis (n 18) 82; Douglas-Scott (n 25) 3.

90 This expression is borrowed from Tobias Lock, 'Human Rights Law in the UK after Brexit' (n 89) 10. 
it to think of the CJEU's constantly expanding case law on the horizontal direct effects of its provisions.

Last but not least, a further interpretation which could be drawn from the foregoing goes against a today's widespread tendency, that is the one to place the (national and supranational) courts at the forefront of the fundamental rights guarantee circuit at the expense of legislators. By contrast, the exclusion of the Charter and the disappearance of the remedy of disapplication go in the direction of rolling the ball back to the political arena: this contributes to a re-establishment of parliamentary sovereignty and reminds that rights protection is not only a task for judges. Also, in the light of this revived responsibility upon the legislature, the next chapters that will follow this latest stage of the narrative of 'bringing rights back home' are a story still to be written. And apparently, it is not possible to write these news pages without accepting to loosen, at least in part, the grip of the courts, even at the cost of political and legal hurdles such as the ones that the UK has encountered so far. 


\section{LIST OF REFERENCES}

Amos M, 'Red Herrings and Reductions: Human Rights and the EU (Withdrawal) Bill' (4 October 2017) UK Constitutional Law Association

Arden L and Tridimas T, 'Limited But Not Inconsequential: The Application of the Charter by the Courts of England and Wales' in Bobek M and Adams-Prassl J (eds), The EU Charter of Fundamental Rights in the Member States (Hart 2020)

DOI: https://doi.org/10.5040/9781509940943.ch-0017

Arnull A, 'Protocol (No 30) on the Application of the Charter of Fundamental Rights of the European Union to Poland and the United Kingdom' in Peers S, Hervey T, Kenner J, Ward A (eds), The EU Charter of Fundamental Rights. A Commentary (Hart 2014)

DOI: https://doi.org/10.5771/9783845259055 1638

Bamforth N, Campbell M, Craig P, Fredman S, Weatherhill S, Alison Young, 'The EU Charter After Brexit' (2017) Oxford Human Rights Hub, Submission to Joint Committee on Human Rights available at: < https://ohrh.law.ox.ac.uk/the-eu-charter-after-brexit2017-submission-to-joint-committee-on-human-rights/>

Barbera A, 'La Carta dei diritti: per un dialogo fra la Corte italiana e la Corte di giustizia' (6 November 2017) AIC available at

< https://www.rivistaaic.it/images/rivista/pdf/4_2017_Barbera.pdf>

Barnard C, 'The 'Opt-Out' for the UK and Poland from the Charter of Fundamental Rights: Triumph of Rhetoric over Reality?' in Griller S and Ziller J (eds), The Lisbon Treaty: EU Constitutionalism Without a Constitutional Treaty? (Springer 2008)

DOI: https://doi.org/10.1007/978-3-211-09429-7 11

Butler G, Meling M, 'Horizontal Direct Effect of the Charter in EU Law: Ramifications for the European Economic Area' (2020) 2 Nordic Journal of European Law 1

DOI: https://doi.org/10.36969/njel.v3i2.22389

Colombi Ciacchi A, 'Egenberger and Comparative Law: A Victory of the Direct Horizontal Effect of Fundamental Rights' (2018) 5 European Journal of Comparative Law and Governance 207

DOI: https://doi.org/10.1163/22134514-00503004

De Burca G, 'The drafting of the European Union Charter of fundamental rights' (2001) 26 European Law Review 126

De Smijter E, Lenaerts K, ‘A “Bill of Rights” for the European Union’ (2001) 38 Common Market Law Review 273 
De Witte B, 'The legal status of the Charter: Vital question or non-issue?’ (2001) 8 Maastricht Journal of European and Comparative Law 81

DOI: https://doi.org/10.1177/1023263x0100800106

Douglas-Scott S, 'Fundamental Rights Not Euroscepticism: Why the UK Should Embrace the EU Charter' (2014) Oxford Legal Studies Research Paper 82/2014 available at $<$ https://papers.ssrn.com/sol3/papers.cfm?abstract id=2528768>

DOI: https://doi.org/10.5040/9781782257905.ch-013

Eeckhout P, 'The EU Charter of Fundamental Rights and the Federal Question' (2002) 39 Common Market Law Review 945

DOI: https://doi.org/10.1023/a:1020832600674

Elliott M, Tierney S, Young A, 'Human Rights Post-Brexit: The Need for Legislation?' (8 February 2018) Public Law for Everyone available at

$<$ www.publiclawforeveryone.com/2018/02/08/human-rights-post-brexit-the-need-forlegislation $/>$

Fatima S, 'The Domestic Application of International Law in British Courts' in Bradley C A (ed), The Oxford Handbook of Comparative Foreign Relations Law (Oxford University Press 2019)

DOI: https://doi.org/10.1093/oxfordhb/9780190653330.013.27

Frantziou E, '(Most of) the Charter of Fundamental Rights Is Horizontally Applicable: ECJ 6 November 2018, Joined Cases C-569/16 and C-570/16, Bauer et Al' (2019) 15 European Constitutional Law Review 306

DOI: https://doi.org/10.1017/s1574019619000166

Frantziou E, 'Mangold Recast? The CJEU's Flirtation with Drittwirkung in Egenberger' (24 April 2018) European Law Blog available at $<$ www.europeanlawblog.eu/2018/04/24/mangold-recast-the-CJEUs-flirtation-withdrittwirkung-in-egenberger/>

Frantziou E, 'The Horizontal Effect of the Charter of Fundamental Rights of the EU: Rediscovering the Reasons for Horizontality' (2015) 21 European Law Journal 657 DOI: https://doi.org/10.1111/eulj.12137

Frantziou E, The Horizontal Effect of Fundamental Rights in the European Union: A Constitutional Analysis (Oxford University Press 2019)

Galimberti M, 'From Good Neighbours to Brothers in Arms? The EU Charter as Avenue for Horizontal Constitutional Interaction', (2021) 1 Europarättslig tidskrift 29 
Garnett R, 'State and Diplomatic Immunity and Employment Rights: European Law to the Rescue?', (2015) 64 International \& Comparative Law Quarterly 783

DOI: https://doi.org/10.1017/s0020589315000366

Gearty C, 'States of denial. What the search for a UK Bill of Rights tells us about human rights protection today' (2018) 5 European Human Rights Law Review 415

Gee G, 'Leaving Strasbourg? Reforming the Human Rights Act', (2015) 3 Quaderni costituzionali 808

Groussot X, 'Direct Horizontal Effect in EU Law after Lisbon - The Impact of the EU Charter of Fundamental Rights on Private Parties' in Lindskoug P et al (eds), Essays in Honour of Michael Bogdan (Juristförlaget 2013)

Groussot X, Pech L, 'Fundamental Rights Protection in the European Union Post Lisbon Treaty' Foundation Robert Schuman Policy Paper 173/2010 available at $<$ https://www.robert-schuman.eu/en/doc/questions-d-europe/qe-173-en.pdf $>$

DOI: https://doi.org/10.2139/ssrn.1628552

Harris B, 'The Charter of Fundamental Rights in UK law after Brexit: Why the Charter should not be transposed' (20 November 2017) Lawyers for Britain available at $<$ https://lawyersforbritain.org/why-the-eus-charter-of-fundamental-rights-must-not-betransposed-into-uk-law>

Horspool M, Humphreys M, Wells-Greco M, European Union Law (Oxford University Press 2018)

DOI: https://doi.org/10.1093/he/9780198818854.001.0001

Lambrecht S, 'Bringing Rights More Home: Can a Home-grown UK Bill of Rights Lessen the Influence of the European Court of Human Rights?' (2014) 15 German Law Journal 407

DOI: https://doi.org/10.1017/s2071832200018976

Lang A, Miller V, Caird S, 'EU (Withdrawal) Bill: the Charter, general principles of EU law, and "Francovich" damages' (2017) House of Commons Library, Research Briefing Paper Number 8140 available at $<$ https://commonslibrary.parliament.uk/researchbriefings/cbp-8140/>

Leczykiewicz D, 'Horizontal Application of the Charter of Fundamental Rights' (2013) 38 European Law Review 479

Lenaerts K, 'Exploring the Limits of the EU Charter of Fundamental Rights' (2012) 8 European Constitutional Law Review 375

DOI: https://doi.org/10.1017/s1574019612000260 
Lock T, 'Human Rights Law in the UK after Brexit' Edinburgh School of Law Research Paper $17 / 2017$

DOI: https://doi.org/10.2139/ssrn.3046554

Lock T, 'What Future for the Charter of Fundamental Rights in the UK?' (6 October 2017) European Futures available at $<$ https://www.europeanfutures.ed.ac.uk/what-future-forthe-charter-of-fundamental-rights-in-the-uk/>

Markakis M, 'Brexit and the EU Charter of Fundamental Rights' (2019) Public Law 82

Martinico G, 'Multiple loyalties and dual preliminarity: The pains of being a judge in a multilevel legal order' (2012) 10 International Journal of Constitutional Law 871

DOI: $\underline{\text { https://doi.org/10.1093/icon/mos027 }}$

McCrea R, 'Religious discrimination at work: Can employees be fired for getting divorced?' (12 September 2018) European Law Blog available at

<www.eulawanalysis.blogspot.com/2018/09/religious-discrimination-at-work-can.html>

McCrea R, 'Salvation outside the church? The CJEU rules on religious discrimination in employment' (18 April 2018) European Law Blog available at

$<$ http:/ / eulawanalysis.blogspot.com/2018/04/salvation-outside-church-ecj-rules-

on.html>

O'Mara C, 'Horizontal enforcement of general principles of EU employment equality law Mangold revisited' (2018) 15 Irish Employment Law Journal 91

O’Neill A, 'The UK Supreme Court and EU law in the Legal Year 2016-2017 - Part 2' (27 October 2017) EUtopia law available at <www.eutopialaw.com/2017/10/27/the-uksupreme-court-and-eu-law-in-the-legal-year-2016-2017-part-2/>

Palmer S, '7 The Human Rights Act 1998: Bringing Rights Home' (1998) 1 Cambridge Yearbook of European Legal Studies 125

DOI: https://doi.org/10.5040/9781472561985.ch-007

Peers S, 'Rights, remedies and state immunity: the Court of Appeal judgment in Benkharbouche and Janah' (6 February 2015) European Law Blog available at <www.eulawanalysis.blogspot.com/2015/02/rights-remedies-and-state-immunity.html>

Sanger A, 'State Immunity and the Right of Access to a Court under the EU Charter of Fundamental Rights' (2016) 65 International \& Comparative Law Quarterly 213

DOI: https://doi.org/10.1017/s0020589315000524

Sanger A, 'The limits of state and diplomatic immunity in employment disputes' (2018) 77 Cambridge Law Journal 1

DOI: https://doi.org/10.1017/s0008197318000120 
Sanger A, 'The State Immunity Act and the Right of Access to a Court' (2014) 73 The Cambridge Law Journal 1

DOI: https://doi.org/10.1017/s0008197314000063

Sarmiento D, 'Sharpening the Teeth of EU Social Fundamental Rights: A Comment on Bauer' (8 November 2018) Despite Our Differences Blog available at

$<$ https://despiteourdifferencesblog.wordpress.com/2018/11/08/sharpening-the-teeth-ofeu-social-fundamental-rights-a-comment-on-bauer/>

Spaventa E, 'The Horizontal Application of Fundamental Rights as General Principles of Union Law' in Arnull A et al (eds), A Constitutional Order of States - Essays in Honour of Alan Dashwood (Hart 2011)

DOI: https://doi.org/10.5040/9781472565402.ch-011

Tridimas T, The General Principles of EU Law (Oxford EC Law Library 1999)

Walkila S, Horizontal Effect of Fundamental Rights in EU Law (Europa Law Publishing 2016)

Webb P, 'The Immunity of States, Diplomats and International Organizations in Employment Disputes: The New Human Rights Dilemma?' (2016) 27 European Journal of International Law 753

DOI: https://doi.org/10.1093/ejil/chw040

Weiler J, 'Does the European Union Truly Need a Charter of Rights?' (2000) 6 European Law Journal 95

DOI: $\underline{\text { https: / / doi.org/10.1111/1468-0386.00098 }}$

Young A, 'Benkharbouche and the future of disapplication' (24 October 2017) UK

Constitutional Law Association available at

$<$ www.ukconstitutionallaw.org/2017/10/24/alison-young-benkharbouche-and-the-future-

of-disapplication/>

Ziegler KS, 'Immunity versus Human Rights: The Right to a Remedy after Benkharbouche' (2017) 17 Human Rights Law Review 127

DOI: https://doi.org/10.1093/hrlr/ngw042 